\title{
Holt-Oram syndrome, bicuspid aortic valve, and patent ductus arteriosus
}

\author{
Paweł Tyczyński', Ilona Michałowska², Barbara Miłosz-Wieczorek², Piotr Hoffman³, Adam Witkowski \\ 'Department of Interventional Cardiology and Angiology, National Institute of Cardiology, Warszawa, Poland \\ 2Department of Radiology, National Institute of Cardiology, Warszawa, Poland \\ ${ }^{3}$ Department of Congenital Heart Disease, National Institute of Cardiology, Warszawa, Poland
}

\author{
Correspondence to: \\ Paweł Tyczyński, MD, PhD, \\ Department of Interventional \\ Cardiology and Angiology, \\ Institute of Cardiology, \\ Alpejska 42, 04-628 Warszawa, \\ phone: +482234342 72, \\ e-mail: medykpol@wp.pl \\ Copyright by the Author(s), 2021 \\ Kardiol Pol. 2021; \\ 79 (12): 1395-1396; \\ DOI: 10.33963/KP.a2021.0118 \\ Received: \\ July 15, 2021 \\ Revision accepted: \\ September 27, 2021 \\ Published online: \\ September 27, 2021
}

Holt-Oram syndrome (HOS) is an autosomal dominant disorder (mutation in TBX5 gene) with the European prevalence of 0.7 per 100000 births [1]. It is characterized by congenital heart defects (CHD) and upper limb abnormalities. Heart defects most commonly include septal defects, followed by aortic coarctation (CoA), mitral valve defects, patent ductus arteriosus (PDA), and conduction disturbances [2]. Defects of the upper limb include thumb anomalies (absent or hypoplastic, triphalangeal, or syndactyly), agenesis/hypoplasia of radius, ulna, or humerus [1]. Moreover, hypoplasia of clavicles and thorax anomalies may also be present [3]. Next, the bicuspid aortic valve (BAV) is the most common CHD (prevalence $0.5 \%-2 \%$ and the entity is associated with valve stenosis or regurgitation, as well as dilatation, aneurysm, and dissection of the ascending aorta (AA). The coexistence of HOS and BAV was most probably described only once. The reported patient presented with multiple cardiac defects (atrial septal defect, BAV, and non-compaction of the left ventricle) [4]. Moreover, only single descriptions (7 reports) of coexistence HOS and PDA have been reported so far ( 2 and others). We report a HOS patient in whom BAV was diagnosed along with PDA.

Three HOS patients were identified among 103330 patients (prevalence $0.003 \%$ ) hospitalized at our institution from January 2008 to November 2020. One of them presented with
BAV. A twenty-eight-year-old male HOS patient after surgical treatment of the aortic coarctation (CoA) and PDA ligation at the age of 7 was admitted for the assessment of the AA. Both transthoracic echocardiography and computed tomography angiography done in 2012 showed the dilated AA up to $51 \mathrm{~mm}$ and BAV with a fusion of the right and left coronary cusps (Figure 1). The patient was offered a redo corrective surgery. However, he preferred a conservative approach and remained under control elsewhere. Repeated transthoracic echocardiography after 9 years (July 2021) showed the AA dilated up to $52 \mathrm{~mm}$. Again, he preferred further observation.

Both CoA and PDA were present in our patient in his childhood. These 2 heart anomalies are characteristic of HOS. Aortic aneurysm, however, is much more characteristic for BAV, and no association of HOS with AA aneurysm was previously reported. The type of BAV in our patient is the most common. Indication for surgical correction of the dilated AA among BAV-population has been described in detail elsewhere. Redo intervention on the AA (and possibly BAV replacement) after previous surgery may increase the peri-procedural risk (EuroSCORE II 2.88). Nonetheless, systematic assessment of the dilated $A A$ is recommended every 6-12 months [5]. Finally, a more than casuistic coexistence of HOS and BAV may not be proven nor excluded in this case. 


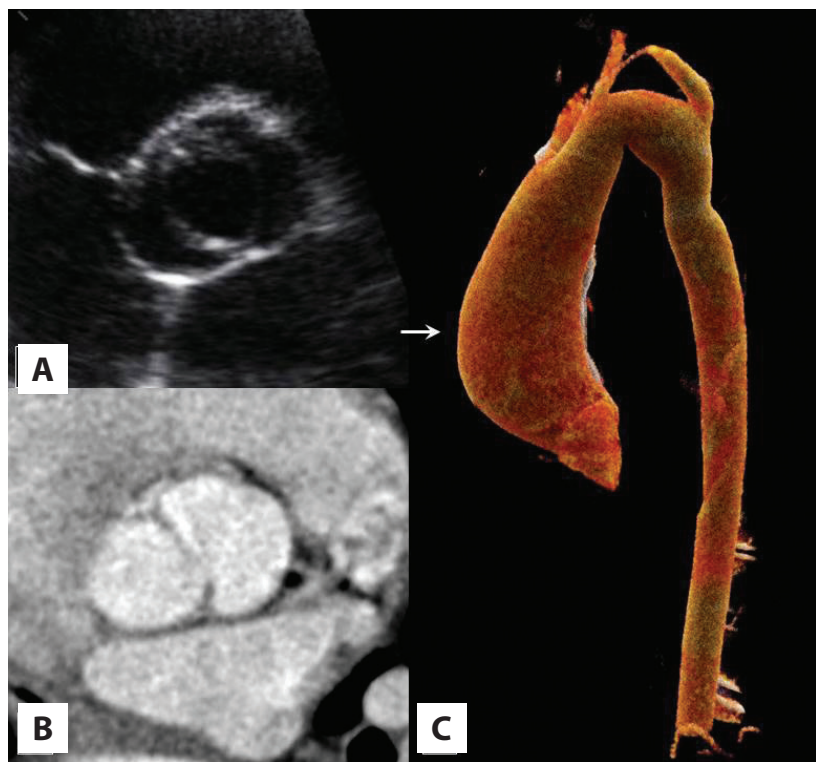

Figure 1. A. and B. Bicuspid aortic valve with commissure fusion between coronary cusps. Corresponding images from echocardiography and computed tomography, respectively. C. Computed tomography angiography. The white arrow indicates a dilated segment of the ascending aorta

\section{Article information}

Conflict of interests: None declared.

Open access: This article is available in open access under Creative Common Attribution-Non-Commercial-No Derivatives 4.0 International (CC BY-NC-ND 4.0) license, allowing to download articles and share them with others as long as they credit the authors and the publisher, but without permission to change them in any way or use them commercially. For commercial use, please contact the journal office at kardiologiapolska@ptkardio.pl.

How to cite: Tyczyński P, Michałowska I, Miłosz-Wieczorek B, et al. Holt-Oram syndrome, bicuspid aortic valve, and patent ductus arteriosus. Kardiol Pol. 2021;79(12):1395-1396, doi: 10.33963/KP.a2021.0118.

\section{REFERENCES}

1. Barisic I, Boban L, Greenlees R, et al. Holt Oram syndrome: a registry-based study in Europe. Orphanet J Rare Dis. 2014; 9: 156, doi: 10.1186/s13023014-0156-y, indexed in Pubmed: 25344219.

2. Vanlerberghe $C$, Jourdain AS, Ghoumid J, et al. Holt-Oram syndrome: clinical and molecular description of 78 patients with TBX5 variants. Eur J Hum Genet. 2019; 27(3): 360-368, doi: 10.1038/s41431-018-0303-3, indexed in Pubmed: 30552424.

3. Newbury-Ecob RA, Leanage R, Raeburn JA, et al. Holt-Oram syndrome: a clinical genetic study. J Med Genet. 1996; 33(4): 300-307, doi: 10.1136/jmg.33.4.300, indexed in Pubmed: 8730285.

4. Spiridon MR, Petris AO, Gorduza EV, et al. Holt-Oram syndrome with multiple cardiac abnormalities. Cardiol Res. 2018; 9(5): 324-329, doi: 10.14740/cr767w, indexed in Pubmed: 30344832.

5. Wang TK, Desai MY. Thoracic aortic aneurysm: optimal surveillance and treatment. Cleve Clin J Med. 2020; 87(9): 557-568, doi: 10.3949/ccjm.87a.19140-1, indexed in Pubmed: 32868306. 